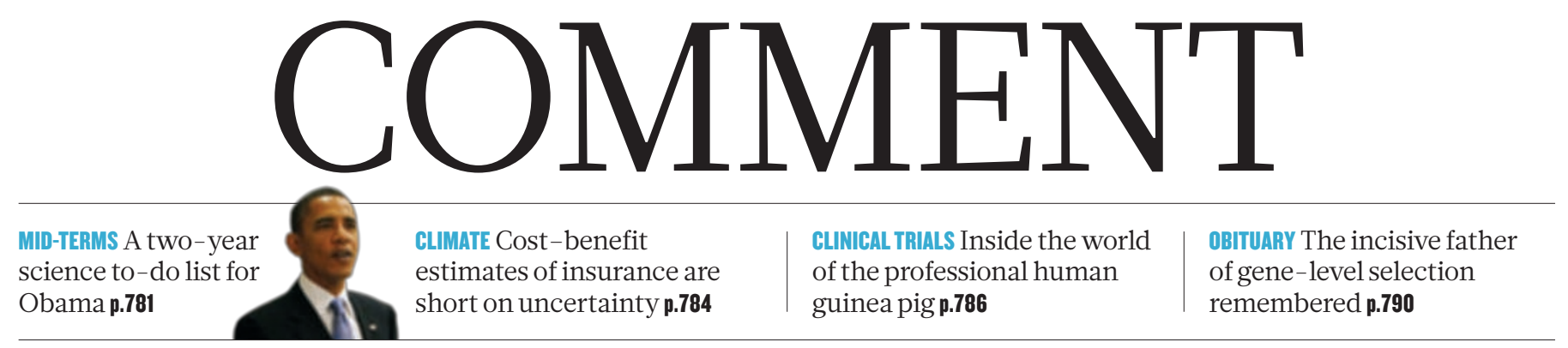

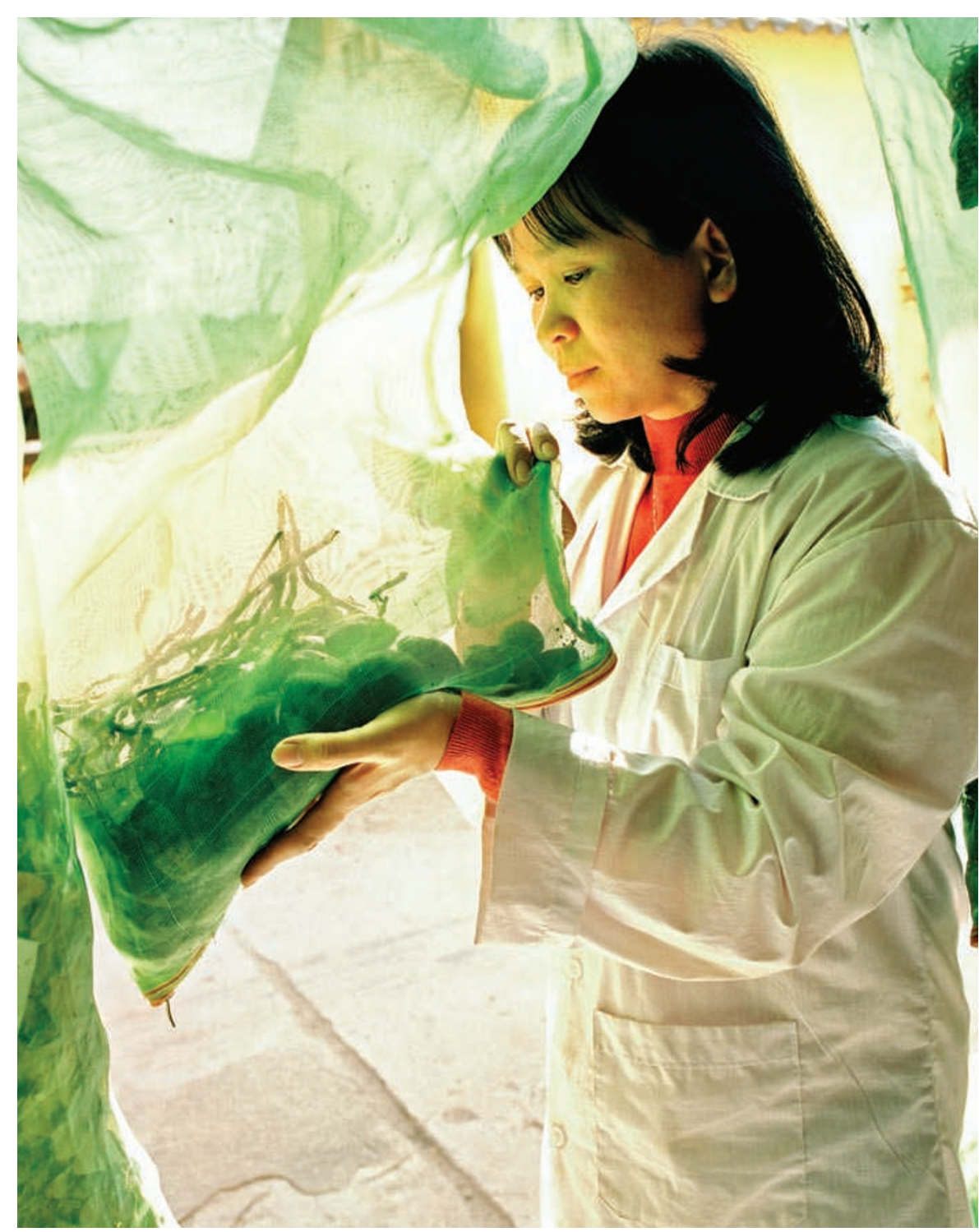

A researcher prepares to analyse plant samples from the biodiversity-rich regions around Hanoi.

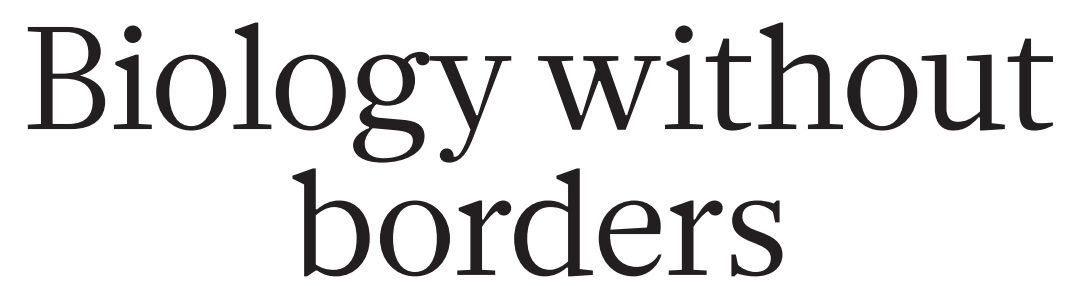

Fundamental research must not be hampered by an international agreement on sharing the benefits from national biodiversity, says David Schindel.
The supreme decision-making body of the United Nations Convention on Biological Diversity (CBD) meets in Nagoya, Japan, on 18-29 October 2010 for its tenth biennial conference. One of the most important items on the agenda is a new protocol which, if enacted, would specify how countries that are parties to the convention control access to their 'genetic resources' (including whole organisms, tissue samples and DNA extracts) and what benefits they can expect from sharing them. The negotiators' focus on genetic resources used to develop commercial products ${ }^{1}$ has left noncommercial academic research in a perilous position ${ }^{2}$. One-size-fits-all legislation could have devastating effects on research conducted by foreign and local investigators, and even on the technological growth and economies of developing countries.

According to the $\mathrm{CBD}$, countries can control access to their own species and set the terms for sharing any benefits resulting from their use by foreigners. Since 1993, only 15 of the 193 countries that have ratified the convention have passed legislation and created regulations to control access (another 58 have either legislation or regulations in place; see 'Where countries stand'). Most are hoping for a long-awaited international agreement to set global standards. The tenth Conference of the Parties (COP-10) could provide this.

Just last month, a CBD working group agreed on a new section to the draft protocol, proposed by the European Union and Japan. This directs CBD countries to encourage research that contributes to the conservation and sustainable use of biodiversity. More specifically, it directs them to create simplified access procedures for non-commercial research, with the understanding that mechanisms for handling unanticipated commercial applications may have to be developed. It is crucial that the parties to the convention approve the global access and sharing agreement only if this amendment is included.

\section{SOVEREIGN RIGHTS}

The rich biological diversity of many developing countries has long attracted biologists interested in evolution and ecology, as well as researchers looking for compounds that could be developed into products such as drugs and cosmetics. Before the creation of the $\mathrm{CBD}$, most government ministries didn't pay much attention to the collecting $>$ 
activities of biologists. Then, beginning in the 1950s, 'bioprospecting' led to the development of highly profitable commercial products. The pharmaceutical company Eli Lilly, for instance, created the anti-cancer drugs vincristine and vinblastine from Catharanthus roseus, the Madagascar periwinkle plant - and it is still not clear which country (or countries), if any, deserve a share of its profits. Environment ministries began to see wild species as valuable natural resources alongside timber and fisheries. Later, the CBD, which came into force at the end of 1993, affirmed that living species were no longer the common heritage of mankind by declaring that "States have sovereign rights over their own biological resources".

One of the objectives of the convention, in addition to conserving species and encouraging sustainable development, is to ensure "the fair and equitable sharing of the benefits arising out of the utilization of genetic resources". To this end, a working group of CBD country representatives (mainly from environment ministries) has been operating since 2004 with the goal of creating an International Regime on Access and Benefit Sharing (IRABS) by the time of COP-10. With the deadline looming, those involved have ramped up their efforts to create a workable agreement. Only in the past six months, however, have the negotiators agreed that the regime should be a legally binding treaty, not a voluntary measure. Also, many crucial issues remain unresolved. It's unclear, for instance, whether - to facilitate urgent research on pandemics - disease-related samples should be exempt, or whether the agreement should cover only material expatriated since the convention came into force.

\section{CAUGHT IN THE CROSSFIRE}

So far, negotiations have been adversarial between at least five stakeholder groups of which only the CBD nations can raise formal objections to the text. First, leaders of biodiversity-rich countries such as Brazil, Indonesia and South Africa want payback for the decades to centuries during which they did not share in the proceeds of species exported for cultivation and commercial exploitation. Second, the heads of industrialized countries such as Canada and members of the European Union want to ensure that their nations' biotechnology sectors can continue to do business without falling into legal quagmires. Third, several non-governmental organizations, such as the ETC Group in Ottawa, Canada, have pilloried virtually all international movement of biological specimens as 'biopiracy'3. Fourth, indigenous communities often consider local species to be their own domain, rather than that of their government, and they seek recognition and reward for their traditional knowledge and conservation efforts.

\section{WHERE COUNTRIES STAND}

The varying extent to which countries have foreign access to genetic resources in accordance with the Convention on Biological Diversity.

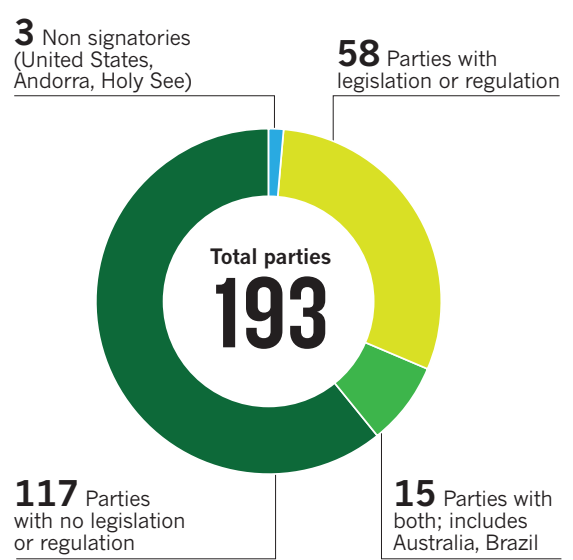
with no legislatior
or regulation Australia, Brazil

Caught in the cross-fire is a fifth group: taxonomists, ecologists and other non-commercial researchers.

In many countries, the decision on whether and when foreign researchers can collect and remove samples is now partly in the hands of provinces and local communities. A taxonomist from the Museum of Natural History in Paris, for example, recently spent two years negotiating with local officials in the Philippines before obtaining a permit to collect species of marine invertebrate. In other countries, such as Indonesia, India or Colombia, waiting periods of a year are common, and many credible projects never gain access. Indeed, separate jurisdictions (for example, from agriculture and environment ministries, or from state as well as local authorities) make it hard even for local researchers to do fieldbased research ${ }^{4}$.

A global agreement - done correctly could remove much of the confusion, save researchers' time and effort, encourage basic ensure a fairer distribution of any benefits.

Admittedly, it can be hard to separate brought in legislation and regulation to control research, reduce governmental costs and

commercial from non-commercial research. Neither can be defined according to who does the work or where a study is conducted. Most big universities have technology-transfer offices devoted to commercializing basic research. A University of Florida researcher invented the sports drink Gatorade, for example. Also, big companies sometimes conduct 'blue sky' research - seven Nobel Prizes have been awarded for work conducted at Bell Labs in Murray Hill, New Jersey.

However, access agreements are generally made one project at a time. So the country providing the biological material could require that each researcher: makes his or her findings public; foregoes any intellectual property rights and activities that might lead to the commercialization of the work; applies for a new agreement should he or she come across something of potential commercial value. Alternatively, agreements could include profit-sharing terms that would come into play if researchers developed commercial intent while carrying out the work. If biologists want to move specimens or samples to a foreign museum, the agreement could specify what downstream uses of the specimens are prohibited - and that any loan transactions be disclosed so that the provider country can track the movement of the samples.

Australia, one of the CBD countries with access regulation and legislation in place, already has streamlined, standardized agreements for foreign researchers wanting to pursue non-commercial research ${ }^{5}$ - where the application process typically takes a few days. In the past 5 years, about 450 permits have been granted, only 10 of which have involved potential commercial applications. Several taxonomists and ecologists studying organisms in marine or hot-spring environments in three of the non-commercial projects recently discovered compounds that may have biomedical or industrial applications. In each case, the researchers have been able to follow a clear and predictable legal process. New commercial access and sharing

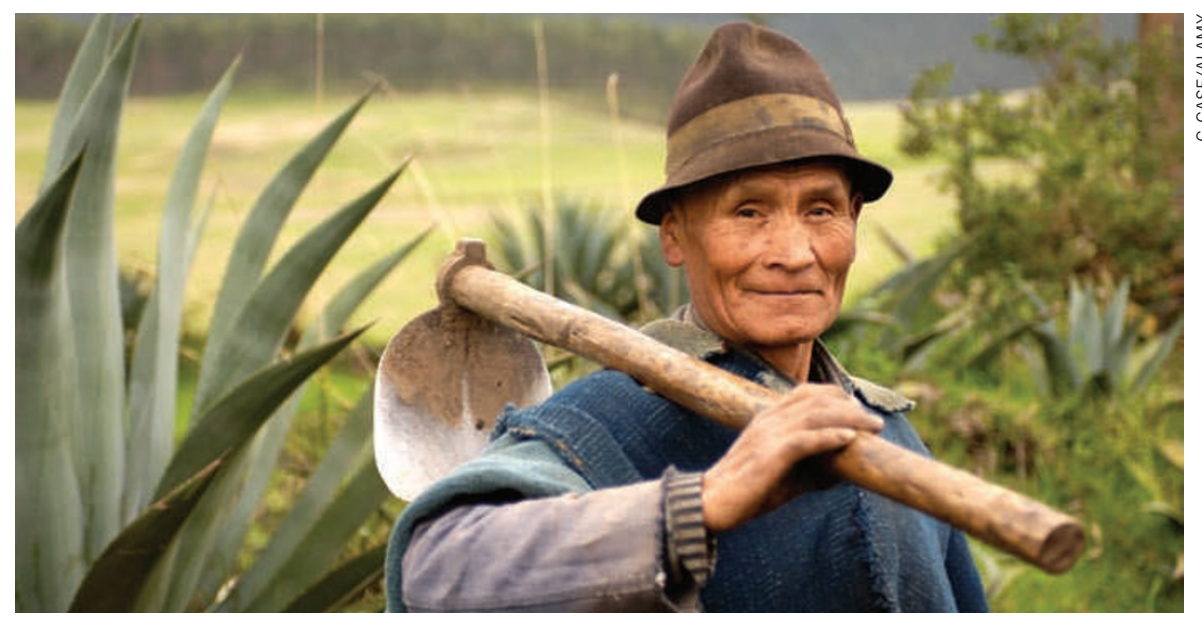

Ecuadorian farmers can better manage land thanks to non-commercial research on local ecology. 
agreements have been negotiated with the environment ministry, allowing them to continue with their research ${ }^{6}$.

Some industrialized countries that want to defend their business sectors may resist demands for greater transparency. In doing so, they will undermine their non-commercial research sectors, which rely on open, trusting relationships with provider countries. On the other side of the fence, some biodiversityrich developing countries may be tempted to demand a defensive, protectionist regime that assumes all research projects are equally likely to yield big commercial benefits. Yet excessive red tape could force non-commercial researchers to conduct their work elsewhere.

If this happens, developing countries will lose on two fronts. The public knowledge created by pure research is essential for countries to support any claims that a commercial product came from samples taken from their territories. Biodiversity inventories and databases, museum collections and DNA bar-coding (www.barcodeoflife.org) - identifying species using short DNA sequences - provide openly accessible documentation of which species occur in which countries. Additionally, international collaborations offer the opportunity to develop universities, museums, scientific expertise and economic growth. Non-commercial research on the ecology of native grasses, trees and shrubs, and invasive plants in Ecuador, for example, is helping local farmers to better manage their land.

With just a few days before COP-10, consensus on the IR-ABS still seems a long way off. All sides should back the text on noncommercial research that was recently added to the draft protocol, regardless of where they stand on other issues relating to the treaty. If not, the CBD's two other long-term goals will be jeopardized: conserving biological diversity and promoting its sustainable use.

David E. Schindel is executive secretary of the Consortium for the Barcode of Life, a global initiative supported by the Alfred $P$. Sloan Foundation and hosted by the National Museum of Natural History, Smithsonian Institution in Washington DC. e-mail: schindeld@si.edu

1. Secretariat of the Convention on Biological Diversity Access and Benefit-Sharing in Practice: Trends in Partnerships Across Sectors, Technical Series No. 38 (2008).

2. Secretariat of the Convention on Biological Diversity Appendix II of the Bonn Guidelines on Access to Genetic Resources and Fair and Equitable Sharing of the Benefits Arising out of their Utilization (2002); available at http://go.nature.com/a8jqao

3. http://go.nature.com/3atq $\times 5$

4. Grajal, A. Conserv. Biol. 13, 6-10 (1999).

5. Australian Natural Resource Management Ministerial Council Nationally Consistent Approach for Access to and the Utilisation of Australia's Native Genetic and Biochemical Resources (2002); available at http://go.nature.com/he7ikv

6. Personal communication from Australia's designated competent national authority for genetic resources.

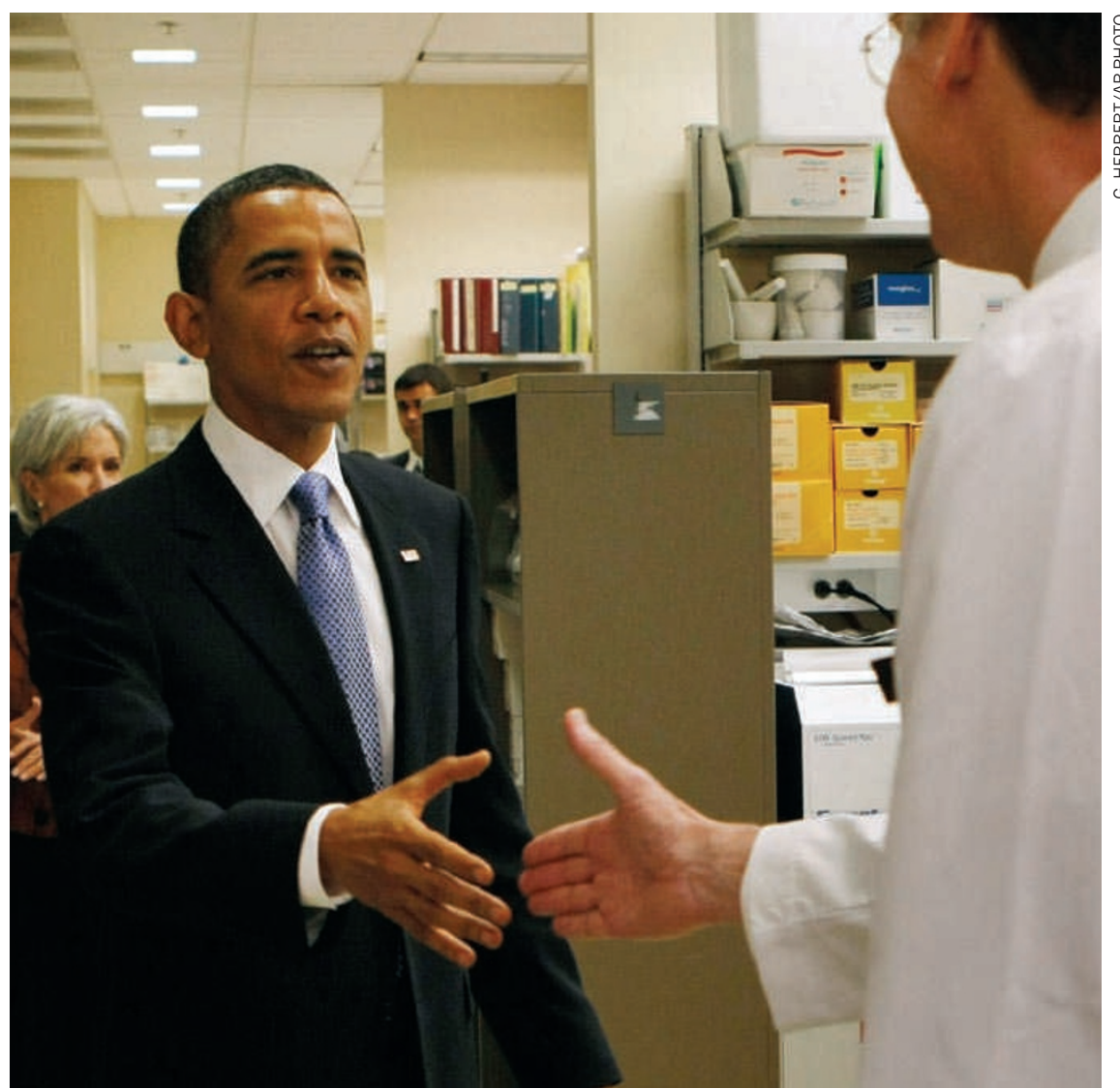

President Barack Obama touring an oncology lab in Bethesda, Maryland, in September 2009.

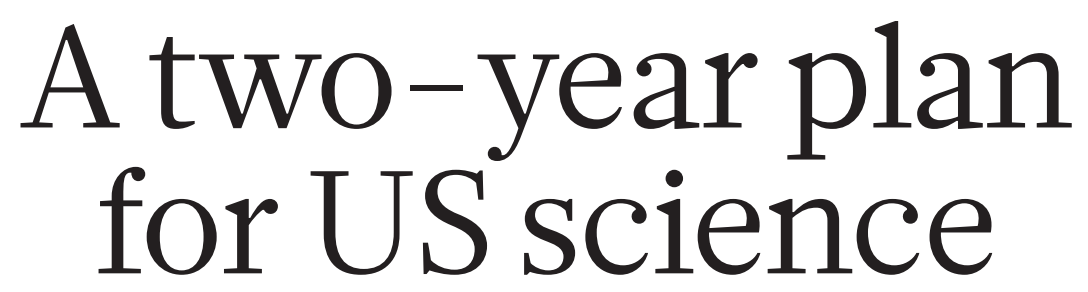

\section{Daniel S. Greenberg sets out five things that the White House and Capitol Hill can and should accomplish between now and the 2012 election.}

$\mathrm{T}$ he widely expected rightward shift in the coming US midterm election reflects hostility to the current government's spending and programmes. Will that be bad for science, with its lifelines to the US treasury? Maybe not. With some exceptions, the scientific enterprise is out of the line of political fire. Both parties trumpet the importance of science. And there's a lot they can do for the enterprise, even with low-growth or stagnant budgets. In most instances, the opening move belongs to the president, who has demonstrated solid support for science.

What should be on Barack Obama's to-do list for science in the next two years? First, assuming little or no increase in total federal research and development (R\&D)

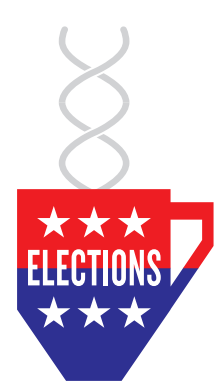

spending, the president should seek to reverse the growing emphasis on defence-related R\&D relative to support for civilian programmes. In the 1970 s, at the height of the cold war, government spending on civilian and military research was about the same. The civilian R\&D budget was even slightly ahead in 1979 , at US $\$ 51.1$ billion, compared to $\$ 48.9$ billion for the Pentagon. Today, defence R\&D accounts for about $59 \%$ of the federal R\&D budget $-\$ 85.3$ billion for the Pentagon, compared with $\$ 60.2$ billion for civilian R\&D. There 